\title{
Niemann-Pick disease type E
}

INSERM

\section{Source}

INSERM. (1999). Orphanet: an online rare disease and orphan drug data base. Niemann-

Pick disease type E. ORPHA:99022

Niemann-Pick disease, type $\mathrm{E}$ is a poorly defined adult-onset and non-neuronopathic form of Niemann-Pick disease. 